\title{
The Correlation between Gifted Students' Cost and Task Value Perceptions towards Mathematics: The Mediating Role of Expectancy Belief
}

\author{
Ahmet Kurnaz \\ Correspondence: Ahmet Kurnaz, Special Education, Gifted and Talented Education, Necmettin Erbakan \\ University-Konya, Turkey.
}

Received: April 11, 2018

doi:10.11114/jets.v6i8.3198
Accepted: June 1, $2018 \quad$ Online Published: June 8, 2018

URL: https://doi.org/10.11114/jets.v6i8.3198

\begin{abstract}
In this study whether the expectancy belief has a mediating role in the correlation between cost value perception and task value perception of gifted students towards mathematics was examined. It is predicted that the correlation between cost value and task value perceptions of gifted students towards mathematics can change according to their expectancy belief levels. This may shed light on the studies aiming to identify the factors affecting gifted students' motivational beliefs towards mathematics and aiming to improve their mathematics performance. This study is conducted through relational screening model. Relational screening models aim to define the presence and degree of change between two or more variables. In this study, the presence and degree of correlation between expectancy belief, task value and task difficulty perceptions of gifted students towards mathematics are examined. 203 fifth and sixth-grade gifted students who were studying at the Art and Science Centers in 12 different cities in Turkey participated in the study. To identify the expectancy belief, task value and cost value perceptions of gifted students participating in the study towards mathematics were measured by Self and Task Perception Questionnaire. According to the results, when expectancy belief is included in the model as a mediating variable, the direct effect of cost on task value decreases and becomes statistically insignificant. In the mediation model, a major part of the direct effect of cost value perception on task value perception occurs through expectancy belief indirectly. It is understood that expectancy belief has a full mediating role in the correlation between cost value and task value perceptions. Expectancy belief of gifted students towards mathematics has a mediating role in the correlation between cost value and task value perceptions. Thus, the expectancy belief perception towards mathematics is of great importance for gifted students and it has a determining role in the correlation between cost value and task value perceptions.
\end{abstract}

Keywords: low case, comma, paper template, abstract, keywords, introduction

\section{Introduction}

In order to train people who could produce knowledge and technology (Ersoy, 1993; Akkoyunlu, 1995; Kahramaner \& Kahramaner, 2002), a county must train people who have higher-order thinking skills, could think faster, make right decisions and produce new ideas. Mathematics is one of the higher order thinking tools. Every school-age child and teenager must learn its value, must believe that he can learn it, must solve mathematics problems and must learn mathematical communication (NCTM, 2000).

Although cognitive skills are important variables in achievement in mathematics (Pajares \& Graham, 1999; Lopez, Lent, Brown \& Gore, 1997; Gainor \& Lent, 1998; Ferla, Valcke \& Cai, 2009; Wang, 2008; Usher \& Pajares, 2009), they alone are not enough (Yurt, 2014). Affective factors are also vitally important in mathematics education (Pahlke, Hyde \& Mertz, 2013; Bilican, Demirtasli \& Kilmen, 2011; Yurt \& Kurnaz, 2014). Especially negative attitudes towards mathematics and having anxiety and stress for it could affect students' mathematics achievement negatively (Işık, Çiltaş \& Bekdemir, 2008).

It is known that motivation is one of the significant affective factors that make students eager to learn mathematics and to participate in activities related to mathematics (Pintrich \& De Groot, 1990; Tella, 2007). According to Wigfield and Eccles (1992) expectancy belief and value perception are two basic resources that feed motivation.

Expectancy belief is defined as the personal beliefs of students about how well they will do a future task. For example, students' beliefs about how successful they will be in mathematics next year reflect their expectancy beliefs towards mathematics (Wigfield \& Eccles, 2000). Value perception which changes from person to person is a combination of 
intrinsic value, extrinsic value, attainment value/importance and cost value perceptions (Eccles, 1983; Wigfield \& Eccles, 1992).

Intrinsic value is the enjoyment one gains from doing a task (Renninger, 2000; Ryan \& Deci, 2000; Schiefele, 2001). When a task is intrinsically valued for an individual, he tends to busy himself with it and to maintain it for a long time. For instance, if a child is interested in solving problems, he probably will take great pleasure in solving mathematics problems and maintain it for a long time. Extrinsic value is not related to interest one shows for a task, but rather it is related to seeing it as a means to achieve his future plans. For example, although one has no interest in mathematics, he studies it to get the profession he wants. This is related to the extrinsic value he attributes to mathematics. That task's bearing attainment value/importance for an individual states that the task is in the center of his sense of self, that it expresses significant aspects of his personality and that it gives the opportunity to reinforce his personality (Battle, 1965; Battle, 1966; Eccles, 1983). For instance, an individual's seeing mathematics as an important part of his personality and using it to express himself are related to attainment value/importance he attributes to mathematics. Cost value refers to what the individual has to give up to do a task, the difficulty of completing a task and the effort one needs to put into it to complete the task. For example, instead of meeting his friends, studying mathematics intensively and for long hours to get high grades from it is related to cost value.

Task-value perception is important to most students; however, it has a different place in gifted students whose affective features are different from the $97 \%$ of the society. Children/students are defined as gifted by specialists when their ability is significantly above the norm for their age. Since the 19th century when giftedness started to be discussed as a scientific concept, the best indicator of giftedness has been the intelligence concept and intelligence tests which are accepted to measure intelligence. In the resources defining giftedness through intelligence tests, giftedness is a title given to individuals who continuously get 130 or higher points from intelligence tests. When we examine the definitions which are independent of intelligence tests, giftedness is a combination of general abilities, personal thoughts and motivation (Feldhusen, 1986), and is defined as asserting an awareness, sensitiveness and ability compared to his peers in terms of abilities of understanding and transferring affective and cognitive experiences (Kokot, 1999). Gagne defines giftedness as turning one's potential into product as a result of the interaction between environment, school, personality, interest, motivation, and attitudes in the mental, creative, social and affective areas (Budak, 2008). One of the most accepted definitions of giftedness is the Renzulli's (1986) three-ring conception of giftedness. These rings are general and special ability level, creativeness and motivation. Motivation is defined as a high task commitment ability in starting and finishing an activity. As is seen in all definitions motivation is directly associated with giftedness. Taylor (1993) suggests that one of the characteristics of gifted individuals is a desire for achievement. The desire to achieve shows that the student has a high intrinsic value.

Renzulli suggests that the concept of motivation is extensive and as a more specific term he puts emphasis on task commitment. Unlike motivation, task commitment contains more specific desires. Self-confidence, ambition, desire, interest, the belief of having the ability to identify and solving significant problems and high personal standards are the components which form the task commitment. Besides these motivational characteristics, having a keen interest in something and integrating himself with an occupation are significant factors that lie under the outstanding inventions and achievements (Reis \& Renzulli, 2010).

Giftedness is often associated with being gifted in mathematics and it is stated that the characteristics of gifted students have a lot in common with the students who are good at mathematics (Niederer et al., 2003; House, 1987; Miller, 1990). Therefore, it can be approved that the general motivation characteristics of gifted individuals are the same as the motivation for mathematics. In fact, gifted students have higher attitude scores for mathematics compared to their peers and if they do not have a second diagnosis such as special learning disability, they feel more qualified in mathematics (Zimmerman \& Cressie,1992). The mathematics performance and academic achievement of the gifted students are higher than their peers (Preckel et al., 2008). High achieving students may also have different motivations for learning mathematics. However, individuals good at mathematics may not have some characteristics of gifted students, and vice versa can be possible (Sheffield, 1999). As is seen there are different explanations for the gifted students' expectations and values towards mathematics.

When the characteristics of gifted students are examined, it is seen that they have consistent and goal-oriented behaviors, and a high desire for learning (Çağlar, 2004). They learn not because their fathers', mothers' or relative's sake, but because to satisfy their desire to learn. They are willing to study hard to achieve high standards and they have the ambition to do the best despite the difficulties (Gallagher, 2008). With these characteristics, their intrinsic motivation for learning is very high. With their wide range of interest areas, potentials to succeed in many fields (VanTassel-Baska, 1990) and high self-confidence, gifted students shape their career plans. These students make long-term plans as well as short-term ones. They define their field of occupation regarding these plans. They attempt to gain the features that they need to reach their plans. These characteristics show that they also have strong extrinsic values. However, it must also 
be stated that mathematics is in their field of interest (Wagner \& Zimmermann; 1986; Chang, 1985). In other words, they have intrinsic values towards mathematics rather than extrinsic values. They have the capacity to show high levels of interest, enthusiasm, perseverance, determination, patience and task commitment (Davasligil, 1991). These characteristics of gifted students point out that they have high cost value perception.

Renzulli (1986) states that while the abilities of gifted students are consistent, their motivational characteristics are changeable. Not all the gifted students keep the same level of productivity, there are ups and downs in their studies. It is stated in many studies that affective characteristics and motivational features deeply affect gifted students (Marland, 1972; as cited in Webb, Meckstroth \& Tolan, 1982).

Although it is thought that basic characteristics of gifted students positively affect their expectancy-value perception, it is estimated that in some cases they cause some negative effects. Gifted students have high expectancies (Silverman, 1994; Clark \& Zimmerman, 1992). The disappointment which results from the failure in achieving these high expectancies may lead to self-hatred and it may turn into hating from school, his friends, and family. If it continues, it causes the loss of sense of belonging (Clark \& Zimmerman, 1992). Trying to achieve high and nonrealistic aims may lead to subversive thoughts and behaviors (Frost \& Marten, 1990). Putting a great value on a single field and accepting success as the only measurement of self-worthiness may result in workaholism (Hess, 1994). One of the characteristics of such students is wasting intrinsic motivation. This characteristic is a state of wanting to use their abilities, seeking for consistency, seeing the possibilities/alternatives, natural motivation, extremely taking the social and moral topics into consideration. Moreover, these students tend to depression, seeking meaning, questioning personality values and experiencing the relationships (Webb, 1982). When the high expectations and values of these students are not managed well, their intrinsic motivation may be wasted.

It is known that gifted students have special interest and ability towards mathematics. Since the general mental abilities of gifted students are almost the same, most of them are thought to be close in strength in terms of fulfilling a mental task. Therefore, when it comes to succeeding in something, their affective characteristics for doing an activity are far more effective than their differences and general mental abilities. Although it is accepted that their cognitive and affective characteristics are generally high, their high-level motivational characteristics may affect gifted students' social and academic life negatively. Thus, gifted students' expectancy and value perception towards mathematics need to be identified.

Even though the cost value is one of the basic elements of expectancy-value theory, it is stated that this basic element is neglected in most of the studies (Wigfield \& Cambia, 2010). In this study, cost value is included to make a contribution to the literature.

It is understood that the direct correlation between cost value, expectancy belief, and task value was examined in the studies conducted in different disciplines and cultures (Witkinson et al, 2005; Xiang et al. (2006); Liu et al., (2009); Luttrell et al., 2010; Trautwein et al., 2012). In this study, it is reported that cost value perception has negative correlations with task value and expectancy belief. Nevertheless, most of these studies focused on the direct correlations between task difficulty perception and task value perception. However, it can be expected that different tacit and mediating variables can exist in the correlation between task difficulty and task value perceptions. For instance, expectancy beliefs of individuals have a determining role in the correlation between task difficulty and task value perceptions.

In fact, in the literature, there are some studies showing that expectancy belief has a determining role in the correlation between cognitive and affective variables towards mathematics. The task difficulty and task value perceptions towards mathematics affect mathematics performance indirectly through expectancy belief. It is found out that expectancy belief has a mediating role in the correlations between ability of solving mathematics problems and mathematics performance (Pajares \& Kranzler, 1995), mathematics ability and mathematics achievement (Randhawa, Beamer \& Lundberg, 1993), mathematics beliefs and mathematics achievement (Kamalimoghaddam et al., 2016), classroom variables and mathematics performance (Fast et al., 2010). The results obtained from the empirical studies showed that expectancy belief affects cognitive and affective characteristics of students towards mathematics by undertaking a mediating role in correlations between different variables. In this study whether the expectancy belief has a mediating role in the correlation between cost value perception and task value perception of gifted students towards mathematics was examined. It is predicted that the correlation between cost value and task value perceptions of gifted students towards mathematics can change according to their expectancy belief levels. This may shed light on the studies aiming to identify the factors affecting gifted students' motivational beliefs towards mathematics and aiming to improve their mathematics performance.

\section{Method}

This study is conducted through relational screening model. Relational screening models aim to define the presence and 
degree of change between two or more variables. In this study, the presence and degree of correlation between expectancy belief, task value and task difficulty perceptions of gifted students towards mathematics are examined.

\subsection{Participant (Subject) Characteristics}

In Turkey, gifted students are given a mental ability test with the guidance of the class teachers in the first three years of their primary school education. After the group ability test, three times as many students as the quota of Science and Art Centers are taken to an individual intelligence test. The students participated in the study were chosen through WISC-R intelligence scale for children. Students who get 130 or more points at this scale are accepted as gifted. In Turkey, no other tests are used to identify gifted students. Sixth-grade gifted students participating in the present study have received a weekly 8 to 10-hour support education service for five years at Science and Art Centers. These students also continue their formal education in their schools and receive no education for gifted students in their schools. The participant students are 12 years old.

\subsection{Sampling Procedures}

Tukey is separated into seven geographical regions. But since Black Sea region lies from west to east like a long strip, it is considered to be two regions as Western and Eastern Black Sea regions. There are 81 cities in these regions. The education of gifted students is carried out at 106 Science and Art Centers located in these 81 city centers. The number of institutions providing education for gifted students is very limited and only $1 \%$ of the gifted students receive education from these institutions. The population of the study consists of 24.291 students studying at 106 Science and Art Centers in 81 cities. 2,368 of these students are studying at sixth grade (MEB, 2017). The sample group of this study consists of 203 sixth-grader gifted students studying at the Science and Art Centers. The sample group is chosen through random sampling method. In random sampling, each member of the population is equally likely to be chosen as part of the sample. Since each member of the population has an equal chance of being selected as sampling unit, whether a group or an individual, more accurate conclusions pertaining to the population can be made. In order to provide the equal chance of being chosen, firstly all the population units, group or individual, must be listed. Then, the sample is chosen through methods such as computer software and drawing lots (Büyüköztürk, 2011). In this study, in order to choose two cities from each of eight regions, Science and Art centers in each region are listed and two cities that are going to be chosen are selected by drawing a lot. For the cities with more than one Science and Art Center, the Science and Art Centers are listed and selected by drawing a lot. As a result, one Science and Art Center from Istanbul and Sakarya, Uşak and Manisa, Adana and Isparta, Ankara and Konya, Zonguldak and Sinop, Rize and Amasya, Van and Erzurum, and Siirt and Gaziantep is chosen from the following regions respectively; Marmara Region, Egean Region, Mediterranean Region, Central Anatolia Region, Western Black Sea Region, Eastern Black Sea Region, Eastern Anatolia Region, Southeastern Anatoli Region. All the sixth-graders studying in these Science and Art Centers are included in the sample. 53\% of these students $(\mathrm{n}=109)$ are girls and $\% 46$ of them $(\mathrm{n}=94)$ are boys.

\subsection{Data Collection Tool}

To identify the expectancy belief, task value and cost value perception of talented students participating in the study towards mathematics were measured by Self and Task Perception Questionnaire originally developed by Eccles and Wigfield (2002) and adapted into Turkish by Yurt and Akyol (2015). The Self and Task Perception Questionnaire includes 19 7-point Likert-type items. The scale includes the following three subscales; expectancy belief, perceived task and cost value. Perceived task value subscale includes the following three sub-dimensions: intrinsic value, attainment value/importance, and extrinsic value. Cost value subscale includes the following two sub-dimensions: task difficulty and required effort. The validity of the Turkish version of the scale was tested with confirmatory factor analysis. Loading factors of the items in intrinsic value, attainment value/importance, extrinsic value, expectancy belief, task difficulty and required effort are calculated respectively as .75-.83, .67-.79, .62-.75, 0.72-.91, .73-.78 and .53-.91. The reliability of the subscales is calculated through Cronbach's alpha reliability coefficient. The obtained coefficients are found between .69 and .92 .

\subsection{Data Collection Process}

To obtain the data for the present study teachers working at Art and Science Centers in İstanbul, Sakarya, Uşak, Manisa, Adana, Isparta, Ankara, Konya, Zonguldak Sinop, Rize, Amasya, Van, Erzurum, Siirt ve Gaziantep are reached. The teachers of the students explain the reason why the data is collected and send the link to the on-line form to the students' e-mail. Students fill in the scale whenever they want in three days. It takes approximately five minutes to fill in the data collection tool.

\subsection{Data Analysis}

Structural equitation model has been used to identify the mediating role of expectancy belief in the correlation between gifted students' cost and task values towards mathematics. In order the mediating role to occur the following factors 
must exist: (i) there must be a significant correlation between the independent variable and mediating variable (ii) depended variable must have a significant effect on independent variable (iii) when the mediating variable is included in correlation between dependent and independent variables, the mediating variable must have a significant effect on the dependent variable whereas the effect of independent variable on dependent variable must decrease (Baron \& Kenny, 1986). In the study the first case is tested through Pearson correlation technique whereas the second and third ones are tested through structural equitation models.

Before conducting the structural equitation model, whether the dataset meets the necessary hypothesis for multiple variable analysis is examined.

Accordingly, the following cases are examined (i) whether the data is normally distributed or not (ii) whether there is a direct relationship between the examined variables (iii) whether there is a multicollinearity problem among the variables (Büyüköztürk at al., 2017). First, whether there are outliers, which make normal distribution difficult in the dataset is examined through Mahalonobis distance. 11 outliers which pose a problem for the multivariate normal distribution are identified and they are excluded from the dataset $\left(\chi_{(6)}^{2}=22.46 ; p<.001\right)$. Secondly, Scatter plot matrixes are formed and examined. It is found out that matrixes are scattered in almost an elliptic shape and that the multivariate normal distribution and linearity are proved largely. Finally, if there is a multicollinearity problem among the variables or not is examined through correlation coefficients. A high correlation ( $r>90)$ between variables shows that there is a multicollinearity problem (Çokluk, Şekercioğlu \& Büyüköztürk, 2010). The correlation values calculated to examine the relationship between variables are found between -.55 and .60 and it is understood that there is not a multicollinearity problem among the variables. The structural equitation model is conducted by using the data of 203 participants.

\section{Findings}

Table 1 shows the mean, standard deviation and Pearson correlation coefficients calculated according to points obtained from self and task perception questionnaire. According to means which are obtained by dividing the points obtained from scale's sub-dimensions to the number of items in those sub-dimensions, expectancy belief $(\mathrm{X}=6.56, \mathrm{Ss}=3.52)$, intrinsic value $(X=5.95, S s=2.54)$, extrinsic value $(X=6.08, S s=2.45)$ and attainment value/importance $(X=6.46$, $\mathrm{Ss}=2.29)$ perceptions of gifted students toward mathematics are found as high, required effort $(\mathrm{X}=4.15, \mathrm{Ss}=7.58)$ perception is found as almost medium level and task difficulty $(X=2.16, S s=3.60)$ perception is found as low.

Table 1. Mean, standard deviation and Pearson correlation coefficients calculated according to points obtained from the self and task perception in mathematics questionnaire

\begin{tabular}{|c|c|c|c|c|c|c|}
\hline Variables & 1. & 2. & 3. & 4. & 5. & 6. \\
\hline 1. Intrinsic Value & 1 & & & & & \\
\hline 2. Attainment Value/Importance & $.54 * *$ & 1 & & & & \\
\hline 3. Extrinsic Value & $.60 * *$ & $.51 * *$ & 1 & & & \\
\hline 4. Expectancy belief & $.49 * *$ & $.56^{* *}$ & $.47 * *$ & 1 & & \\
\hline 5. Task Difficulty & $-.46 * *$ & $-.46 * *$ & $-.30 * *$ & $-.55^{* *}$ & 1 & \\
\hline 6. Required Effort & .09 & .09 & $.18^{*}$ & $-.19 * *$ & $.27 * *$ & 1 \\
\hline $\mathrm{X}$ & 11,89 & 19.39 & 12.15 & 32.82 & 6.47 & 16.60 \\
\hline Ss & 2,54 & 2.29 & 2.45 & 3.52 & 3.60 & 7.58 \\
\hline $\mathrm{X} /$ Number of items & 5,95 & 6.46 & 6.08 & 6.56 & 2.16 & 4.15 \\
\hline
\end{tabular}

$* * p<.01, * p<.05$

In order to identify the mediating role of expectancy belief in the correlation between task and cost values of gifted students towards mathematics, first of all, the direct correlation between cost value and task value is tested and the path coefficient is found as -.68 (figure 1). It is found out that the tested model has good adaptive values $(\chi 2 / \mathrm{sd}=3.56$, RMSEA=.1, SRMR=0.04, CFI=0.97, GFI=0.98, AGFI=0.91 and IFI=0.97) (Bentler \& Bonett, 1980; Bollen, 1989; Jöreskog \& Sörbom, 1984; McDonald \& Marsh, 1990; Marsh \& Hocevar, 1985; Tanaka \& Huba, 1985).

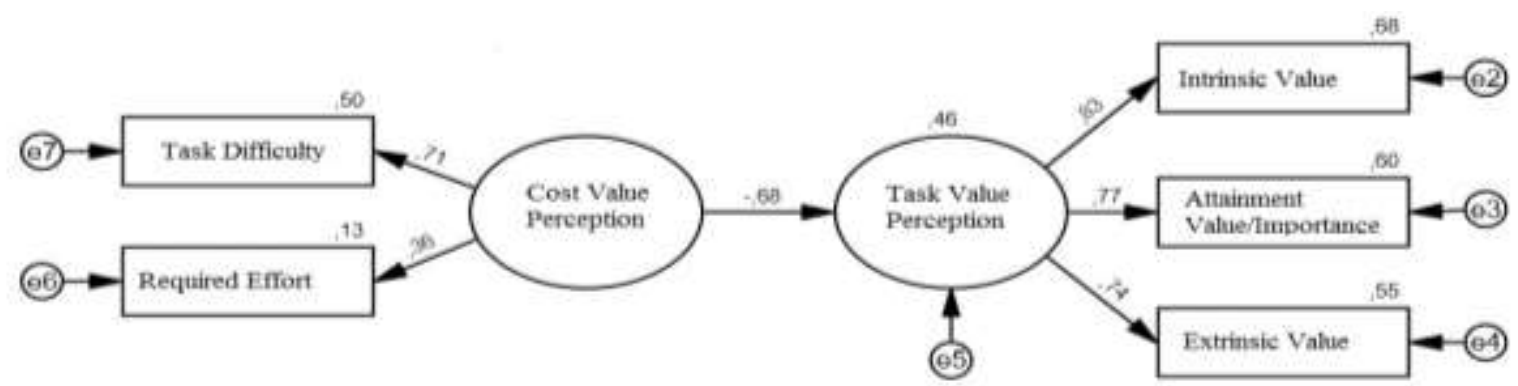

Figure 1. The structural model for cost and task value variables 
In the next step, expectancy belief is included in the correlation between cost and task values as a mediating variable and this new model is tested. With regard to the analysis results, it is found that the tested model has good adaptive values $(\chi 2 / \mathrm{sd}=3.54, \mathrm{RMSEA}=.1, \mathrm{SRMR}=0.06, \mathrm{CFI}=0.97, \mathrm{GFI}=0.97, \mathrm{AGFI}=0.90$ and $\mathrm{IFI}=0.97)$ (Bentler \& Bonett, 1980; Bollen, 1989; Jöreskog \& Sörbom, 1984; McDonald \& Marsh, 1990; Marsh \& Hocevar, 1985; Tanaka \& Huba, 1985).

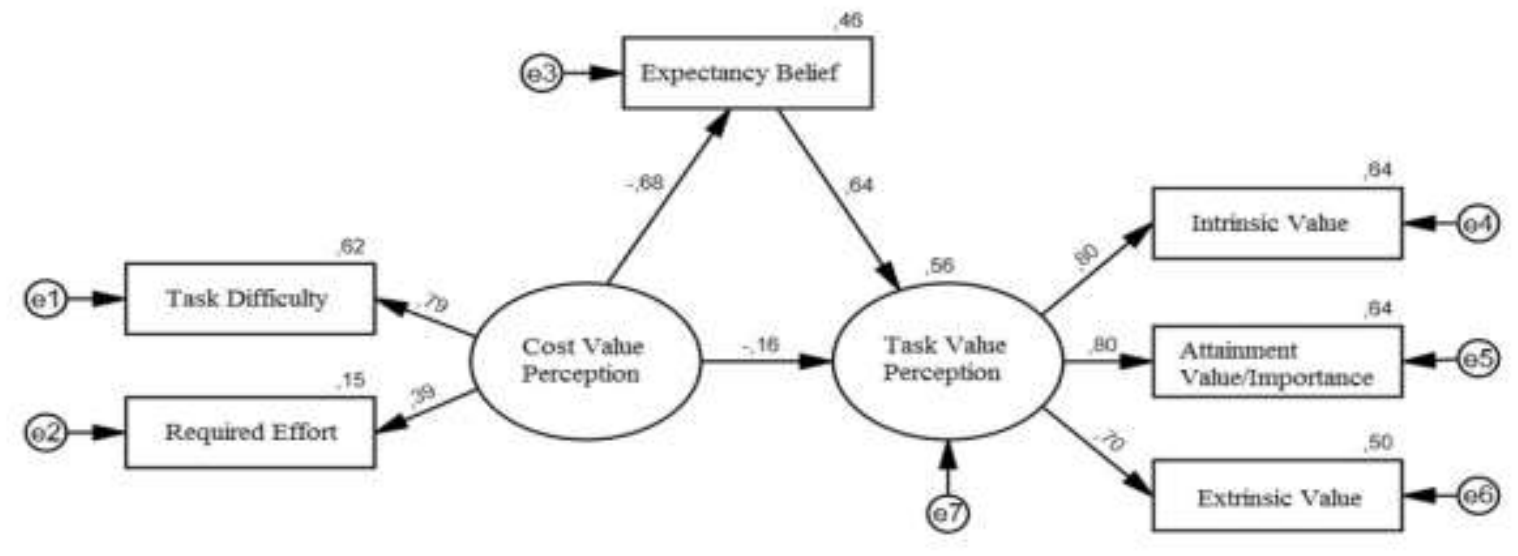

Figure 2. The structural model of the cost value perception, expectancy belief, and task value.

As is seen in figure 1 the direct effect of cost value perception on task value perception is -.68. In the model in figure 2 it is seen that when the expectancy belief is included as a mediating variable, the effect of cost value perception on task value perception is -.16. The decrease in the path coefficient means that expectancy belief has a mediating role in the correlation between cost value and task value perceptions. Thus, it can be suggested that gifted students' cost value perceptions towards mathematics affect their task value perceptions and expectancy belief has a mediating role in this correlation. To determine whether the expectancy belief has a full or partial mediating effect, the significance level of the direct and indirect effects in the model in figure 2 is examined through bootstrap analysis. According to the results, it is found out that when the expectancy belief is included in the model, the direct effect of cost value perception on task value perception is not significant. Hence it can be suggested that cost value perception effects task value perception and expectancy belief has a full mediating role in this correlation (Table 2).

Table 2. The direct and indirect effects between cost value, expectancy belief and task value

\begin{tabular}{cccccc}
\hline $\begin{array}{c}\text { Independent } \\
\text { Variable }\end{array}$ & $\begin{array}{c}\text { Mediating } \\
\text { Variable }\end{array}$ & $\begin{array}{c}\text { Dependent } \\
\text { Variable }\end{array}$ & $\begin{array}{c}\text { Direct effect without the } \\
\text { mediating variable }\end{array}$ & $\begin{array}{c}\text { Direct Effect with the } \\
\text { mediating variable }\end{array}$ & $\begin{array}{c}\text { Indirect } \\
\text { Effect }\end{array}$ \\
\hline $\begin{array}{c}\text { Cost Value } \\
\text { Perception }\end{array}$ & $\begin{array}{c}\text { Expectancy } \\
\text { belief }\end{array}$ & $\begin{array}{c}\text { Task Value } \\
\text { Perception }\end{array}$ & $-.68(\mathrm{p}=.003)$ & $-.16(\mathrm{p}=.299)$ & -.43 \\
$(\mathrm{p}=.004)$
\end{tabular}

It is seen that gifted students' cost value perception towards mathematics has a direct effect on task value perception. That they see mathematics as an easy task affects value they put into mathematics. Perceiving a task as easy and the individual's perception of how much effort they have to exert to complete it are closely related to cost value (Eccles \& Wigfield, 2002; Wigfield \& Eccles, 1992; Wigfield et al., 2009). It has been stated that cost plays an important role especially in individuals' task preferences (Eccles, 1983). It is highly probable that tasks requiring low effort will be preferred by individuals. As the results of this study show that gifted students have a medium level of required effort and low level of task value towards mathematics, gifted students think that they can be successful in mathematics with a medium level of effort.

\section{Results}

It is found out that gifted student's cost value perceptions towards mathematics affect their task value perceptions and expectancy belief has a full mediating role in this correlation. Accordingly, cost value has an effect on task value perception of gifted students towards mathematics, but when expectancy belief is included in the model, it is seen that expectancy belief has a higher effect on task value. According to expectancy-value theory, expectancy belief is one of the most important elements of motivation. Expectancy belief defines the individuals' perception of how successful they are now and will be in the future in mathematics. For example, a student's perception of how successful he will be in mathematics next year reflects his expectancy towards succeeding in mathematics. An individual's expectancy belief is closely related to the answer he gives to the question: "will I fulfill this task" (Pintrich \& De Groot, 1990). With this 
study, it is suggested that this result of expectancy-value theory is also true for the gifted students. In the studies conducted in this field, it is pointed out that value perception affects individuals' performances, task selections and achievements (Andersen \& Ward, 2014; Bong, 2001; Eccles, 1993; Cox \& Whaley, 2004; Dennissen, Zarret \& Eccles, 2007; Durik et al., 2006; Simpkins, Davis-Kean \& Eccles, 2006). It is determined that expectancy belief is the strongest predictor of performance while other components have more effect over the onset and continuance of activities (Wigfield \& Cambria, 2010). Studies examining the relationship between expectancy belief and value perception state that individuals tend to put more effort into activities they think themselves competent and they endeavor more to participate in these activities (Graham \& Williams, 2009; Jacobs, Lanza, Osgood, Eccles \& Wigfield, 2002; Wigfield et al., 1997; Wigfield \& Eccles, 1992). It is known that there is a relationship between higher-order cognitive skills and mathematical skills (Wrigley, 1958; Guilford, 1967; Koshy et al., 2009). Mathematical skill is defined as feeling powerful while using his mathematical knowledge in dealing with tasks and activities related to mathematics and as fulfilling tasks related to it (Koshy et al., 2009). Therefore, gifted students' seeing themselves competent enough in mathematics is the most prominent indicator of their value perception towards mathematics.

\section{Discussion}

In the light of theoretical explanations and empirical studies, this paper argues that gifted students' expectancy beliefs toward mathematics have a mediating role in the correlation between cost and task value perceptions. Accordingly, by including basic models into the analysis process, whether or not there is a mediating effect is examined. According to the results obtained from the study, when expectancy belief is included in the model as a mediating variable, the direct effect of cost on task value decreases and becomes statistically insignificant. In the mediation model, a major part of the direct effect of cost on task value perception occurs through expectancy belief indirectly. It is understood that expectancy belief has a full mediating role in the correlation between cost and task value perceptions. This result supports results of the studies suggesting that expectancy belief has a mediating role in relationships between cognitive and affective variables towards mathematics (Pajares and Kranzler, 1995; Randhawa, Beamer \& Lundberg, 1993; Kamalimoghaddam et al., 2016; Fast et al., 2010).

Cost is the negative factors that dissuade individuals from performing a task or participating in an activity. Individuals always take into consideration cost in their choices. The difficulty level of a task and how much effort it requires are closely related to the cost value (Eccles \& Wigfield, 2002; Wigfield \& Eccles, 1992; Wigfield et al., 2009). A student who has a high cost perception towards mathematics thinks mathematics as a hard and demanding subject. Task value is a combination of intrinsic value, extrinsic value, and attainment value/importance. A student who has a high task value perception towards mathematics enjoys dealing with it, sees mathematics as an important tool to achieve his future goals and sees mathematics as an important subject to express prominent aspects of his self. This student also regards mathematics as an important subject that reflects his academic personality. The former studies show that there is a negative correlation between cost and task value perceptions (Witkinson et al, 2005; Xiang et al., 2006; Liu et al., 2009; Luttrell et al., 2010; Trautwein et al., 2012). That is, a student who considers mathematics to be a hard and demanding lesson does not enjoy dealing with it and does not regard it as a useful and important subject which reflects his academic personality.

The results obtained from this study show that expectancy belief of gifted students participating in this study towards mathematics has a mediating role in the correlation between cost value and task value perceptions. Namely, the level of expectancy belief of an individual towards mathematics affects his task value perception and this positively or negatively reflected on the value he puts into mathematics. For example, a student who gets the highest marks in mathematics in the class sees mathematics as a rather easy subject. Because this student has successful experiences related to mathematics. It is more likely that this student shows more interest in mathematics, plans his career in fields related to mathematics, and sees mathematics as a prominent part of his self. It is stated that individuals tend to value activities they see themselves competent and put more effort to participate in these activities (Graham \& Williams, 2009; Jacobs, Lanza, Osgood, Eccles \& Wigfield, 2002; Wigfield et al., 1997). On the contrary, a student who has unsuccessful experiences in mathematics will see it as a hard and demanding subject. Accordingly, this student may stay away from activities related to mathematics and may tend to put less value on mathematics by turning his interest into the fields in which he is more successful. According to these explanations it is understood that expectancy belief is an important variable which is associated with cost and task value perceptions and which can affect them in a negative or positive way.

The findings obtained from this study suggest that expectancy belief towards mathematics is quite important for gifted students and that it plays an important role in the correlation between cost and task value perceptions. Expectancy belief has four main sources and these are; personal experiences, vicarious experiences, verbal persuasions and physiological situations (Bandura, 1997). Especially personal experiences are accepted as the most significant source of expectancy belief towards mathematics (Joët et al., 2011; Usher \& Pajares, 2009; Usher and Pajares, 2006). In this respect, suitable 
environments and programs must be prepared for gifted students to have efficient, successful and proper experiences in mathematics. Thus, gifted students can have high expectancy beliefs towards mathematics. Consequently, it must be ensured that these students keep their interests and desires to learn mathematics, shape their careers in fields related to mathematics and see it as a prominent part of their academic personality.

\section{References}

Akkoyunlu, B. (1995). Bilgi teknolojilerinin okullarda kullanımı ve öğretmenlerin rolü. Hacettepe Üniversitesi Eğitim Fakültesi Dergisi, 11(11).

Andersen, L., \& Ward, T. J. (2014). Expectancy-value models for the STEM persistence plans of ninth-grade, highability Students: A comparison between black, hispanic, and white students. Science Education, 98(2), 216-242. https://doi.org/10.1002/sce.21092

Bandura, A. (1997). Self-efficacy: The exercise of control. Macmillan.

Baron, R. M., \& Kenny, D. A. (1986). The moderator-mediator variable distinction in social psychological research: Conceptual, strategic, and statistical considerations. Journal of Personality and Social Psychology, 51(6), 1173. https://doi.org/10.1037/0022-3514.51.6.1173

Battle, E. S. (1965). Motivational determinants of academic task persistence. Journal of Personality and Social Psychology, 2(2), 209. https://doi.org/10.1037/h0022442

Battle, E. S. (1966). Motivational determinants of academic competence. Journal of Personality and Social Psychology, 4(6), 634. https://doi.org/10.1037/h0024028

Bentler, P. M., \& Bonett, D. G. (1980). Significance tests and goodness of fit in the analysis of covariance structures. Psychological Bulletin, 88, 588-606. https://doi.org/10.1037/0033-2909.88.3.588

Bilican, S., Demirtasli, R. N., \& Kilmen, S. (2011). The attitudes and opinions of the students towards mathematics course: The comparison of TIMSS 1999 and TIMSS 2007. Educational Sciences: Theory and Practice, 11(3), 1277-1283.

Bollen, K. A. (1989). A new incremental fit index for general structural equation models. Sociological Methods and Research, 17, 303-316. https://doi.org/10.1177/0049124189017003004

Bong, M. (2001). Between-and within-domain relations of academic motivation among middle and high school students: Self-efficacy, task value, and achievement goals. Journal of Educational Psychology,93(1), 23. https://doi.org/10.1037/0022-0663.93.1.23

Budak, G. (2008). Yetkinliğe dayalı insan kaynakları yönetimi. İzmir: Barış Yayınları.

Büyüköztürk, Ş. (2011). Sosyal bilimler için veri analizi el kitabı. Ankara: Pegem Akademi. https://doi.org/10.14527/9789944919289

Büyüköztürk, Ş., Çakmak, E. K., Akgün, Ö. E., Karadeniz, Ş., \& Demirel, F. (2017). Bilimsel araştırma yöntemleri (6th ed.). Ankara: Pegem Yayınları.

Çağlar, D. (2004). Üstün zekâlı çocukların özellikleri. (Editör: Adnan Kulaksızoğlu, Ahmet Emre Bilgili, Mustafa Ruhi Şirin). I. Türkiye Üstün Yetenekli Çocuklar Kongresi Üstün Yetenekli Çocuklar Bildiriler Kitabı. İstanbul: Çocuk Vakfi Yayınları, 7-8.

Clark, G. A., \& Zimmerman, E. (1992). Issues and practices related to identification of gifted and talented students in the visual arts (No. 9202). National Research Center on the Gifted and Talented.

Çokluk, Ö., Şekercioğlu, G., \& Büyüköztürk, Ş. (2010). Multivariate statistics for the social sciences: SPSS and LISREL applications. Ankara: Pegem Akademi.

Cox, A. E., \& Whaley, D. E. (2004). The influence of task value, expectancies for success, and identity on athletes' achievement behaviors. Journal of Applied Sport Psychology, 16(2), 103-117. https://doi.org/10.1080/10413200490437930

Davaslıgil, Ü. (1991). Üstün olma niteliğini kazanma. Ĕgitim ve Bilim, 15(82).

Eccles, J. S. (1983). Expectancies, values, and academic behaviors. In J. T. Spence (Ed.), Achievement and achievement motivation: Psychological and sociological approaches (pp. 75-146). San Francisco, CA: Free man.

Eccles, J. S., \& Wigfield, A. (2002). Motivational beliefs, values, and goals. Annual Review of Psychology, 53(1), 109-132. https://doi.org/10.1146/annurev.psych.53.100901.135153

Ersoy, Y. (1993). Bilgi çağı ve matematik eğitimi: Dönüşümler ve yeni eğilimler. MESEM-93, 21-22 Ankara: ODTÜ. 
Feldhusen, J. F. (1986). A conception of giftedness. In K. A. Heller \& J. F. Feldhusen (Eds.) Identifying and nurturing the gifted: An international perspective (pp. 33-39). Toronto: Hans Huber Publishers.

Ferla, J., Valcke, M., \& Cai, Y. (2009). Academic self-efficacy and academic self-concept: Reconsidering structural relationships. Learning and Individual Differences, 19(4), 499-505. https://doi.org/10.1016/j.lindif.2009.05.004

Frost, R. O., \& Marten, P. A. (1990). Perfectionism and evaluative threat. Cognitive Therapy and Research, 14(6), 559-572. https://doi.org/10.1007/BF01173364

Gainor, K. A., \& Lent, R. W. (1998). Social cognitive expectations and racial identity attitudes in predicting the math choice intentions of Black college students. Journal of Counseling Psychology,45(4), 403. https://doi.org/10.1037/0022-0167.45.4.403

Gallagher, T. (2008). Young people in post-conflict Northern Ireland. In D. Schubotz \& P. Devine (Eds.) Diversity or division? Experiences of education in Northern Ireland. Dorset: Russell House Publishing.

Graham, S., \& Williams, C. (2009). An attributional approach to motivation in school. In K. R. Wentzel \& A. Wigfield (Eds.) Handbook of motivation at school (pp. 11-34). New York: Routledge.

House, P. A. (1987). Providing opportunities for the mathematically gifted, $k$-12. Reston, VA: National Council of Teachers of Mathematics.

Işık, A., Çiltaş, A., \& Bekdemir, M. (2008). Matematik eğitiminin gerekliliği ve önemi. Atatürk Üniversitesi Kazım Karabekir Eğitim Fakültesi Dergisi, (17).

Jacobs, J. E., Lanza, S., Osgood, D. W., Eccles, J. S., \& Wigfield, A. (2002). Changes in children's self-competence and values: Gender and domain differences across grades one through twelve. Child Development, 73(2), 509-527. https://doi.org/10.1111/1467-8624.00421

Joët, G., Usher, E. L., \& Bressoux, P. (2011). Sources of self-efficacy: An investigation of elementary school students in France. Journal of Educational Psychology, 103(3), 649-663. https://doi.org/10.1037/a0024048

Jöreskog, K. G., \& Sörbom, D. (1984). LISREL-VI user's guide (3rd ed.). Mooresville, IN: Scientific Software.

Kahramaner, Y., \& Kahramaner, R. (2002). Üniversite egitiminde matematik düşüncesinin önemi. İstanbul Ticaret Üniversitesi Dergisi, 15-25.

Kamalimoghaddam, H., Tarmizi, R. A., Ayub, A. F. M., \& Jaafar, W. M. W. (2016). The influences of mathematics beliefs on mathematics achievement through mathematics self-efficacy: A structural equation model. Communication in Mathematical Modeling and Application, 1(1), 44-51.

Kokot, J. S. (1999). Help our child is gifted: Guidelines for parents og gifted children (2nd ed.). Lyttelton, Republic of South Africa: Radford House Publication.

Kokot, R. B. (2011). Principles and practice of structural equation modeling (3rd ed.). New York: The Guilford Press.

Koshy, V., Ernest, P., \& Casey, R. (2009). Mathematically gifted and talented learners: Theory and practice. International Journal of Mathematical Education in Science and Technology, 40(2), 213-228. https://doi.org/10.1080/00207390802566907

Liu, J., Chen, G., Song, X., Chi, I., \& Zheng, X. (2009). Trends in disability-free life expectancy among Chinese older adults. Journal of Aging and Health, 21(2), 266-285. https://doi.org/10.1177/0898264308328978

Lopez, F. G., Lent, R. W., Brown, S. D., \& Gore, P. A. (1997). Role of social-cognitive expectations in high school students' mathematics-related interest and performance. Journal of Counseling Psychology, 44(1), 44. https://doi.org/10.1037/0022-0167.44.1.44

Luttrell, V. R., Callen, B. W., Allen, C. S., Wood, M. D., Deeds, D. G., \& Richard, D. C. (2010). The mathematics value inventory for general education students: Development and initial validation. Educational and Psychological Measurement, 70(1), 142-160. https://doi.org/10.1177/0013164409344526

Marsh, H. W., \& Hocevar, D. (1985). Application of confirmatory factor analysis to the study of self-concept: First and higher-order factor models and their invariance across groups. Psychological Bulletin, 97, 562-582. https://doi.org/10.1037/0033-2909.97.3.562

McDonald, R. P., \& Marsh, H. W. (1990). Choosing a multivariate model: Noncentrality and goodness of fit. Psychological Bulletin, 107, 247-255. https://doi.org/10.1037/0033-2909.107.2.247

Miller, R. C. (1990). Discovering mathematical talent. Reston VA: ERIC Clearinghouse on Handicapped and Gifted Children. 
MNE., (2017). Ministry of National Education 2016-2017 academic year statistics. Retrieved from at 05.02.2018 http://sgb.meb.gov.tr/meb_iys_dosyalar/2017_09/08151328_meb_istatistikleri_orgun_egitim_2016_2017.pdf

National Council for Teachers of Mathematics (NCTM). (2000). Principles and standards for school mathematics. Reston, VA: NCTM.

Niederer, K., Irwin, R. J., Irwin, K. C., \& Reilly, I. L. (2003). Identification of mathematically gifted children in New Zealand. High Ability Studies, 14(1), 71-84. https://doi.org/10.1080/13598130304088

Pahlke, E., Hyde, J. S., \& Mertz, J. E. (2013). The effects of single-sex compared with coeducational schooling on mathematics and science achievement: Data from Korea. Journal of Educational Psychology, 105(2), 444. https://doi.org/10.1037/a0031857

Pajares, F., \& Graham, L. (1999). Self-efficacy, motivation constructs, and mathematics performance of entering middle school students. Contemporary Educational Psychology, 24(2), 124-139. https://doi.org/10.1006/ceps.1998.0991

Pajares, F., \& Kranzler, J. (1995). Self-efficacy beliefs and general mental ability in mathematical problem-solving. Contemporary educational psychology, 20(4), 426-443. https://doi.org/10.1006/ceps.1995.1029

Pintrich, P. R., \& De Groot, E. V. (1990). Motivational and self-regulated learning components of classroom academic performance. Journal of Educational Psychology, 82(1), 33. https://doi.org/10.1037/0022-0663.82.1.33

Preckel, F., Goetz, T., Pekrun, R., \& Kleine, M. (2008). Gender differences in gifted and average-ability students: Comparing girls' and boys' achievement, self-concept, interest, and motivation in mathematics. Gifted Child Quarterly, 52(2), 146-159. https://doi.org/10.1177/0016986208315834

Randhawa, B. S., Beamer, J. E., \& Lundberg, I. (1993). Role of mathematics self-efficacy in the structural model of mathematics achievement. Journal of Educational Psychology, 85, 41-44. https://doi.org/10.1037/0022-0663.85.1.41

Reis, S. M., \& Renzulli, J. S. (2010). Is there still a need for gifted education? An examination of current research. Learning and individual differences, 20(4), 308-317. https://doi.org/10.1016/j.lindif.2009.10.012

Renninger, K. A. (2000). Individual interest and its implications for understanding intrinsic motivation. In C. Sansone \& J. M. Harackiewicz (Eds.), Intrinsic and extrinsic motivation: The search for optimal motivation and performance (pp. 373-404). San Diego, CA: Akademic Press. https://doi.org/10.1016/B978-012619070-0/50035-0

Renzulli, J. S. (Ed.). (1986). Systems and models for developing programs for the gifted and talented. Creative Learning Pr.

Ryan, R. M., \& Deci, E. L. (2000). Intrinsic and extrinsic motivations: Classic definitions and new directions. Contemporary Educational Psychology, 25(1), 54-67. https://doi.org/10.1006/ceps.1999.1020

Schiefele, U. (2001). The role of interest in motivation and learning. In J. M. Collis \& S. Messic (Eds.), Intelligence and personality: Bridging the gap in theory and measurement (pp. 163-194). Mahwah, New Jersey: Lawrence Erlbaum Associates, Inc, Publishers.

Sheffield, L. J. (1999). Developing mathematically promising students. Teaching Children Mathematics, 6(4), 273-273.

Silverman, L. K. (1994). The moral sensitivity of gifted children and the evolution of society. Roeper Review, 17(2), 110-116. https://doi.org/10.1080/02783199409553636

Simpkins, S. D., Davis-Kean, P. E., \& Eccles, J. S. (2006). Math and science motivation: A longitudinal examination of the links between choices and beliefs. Developmental Psychology, 42(1), 70. https://doi.org/10.1037/0012-1649.42.1.70

Tanaka, J. S., \& Huba, G. J. (1985). A fit index for covariance structure models under arbitrary GLS estimation. British $\begin{array}{lllll}\text { Journal of Mathematical and Statistical Psychology, } & 38, & \text { 197-201. }\end{array}$ https://doi.org/10.1111/j.2044-8317.1985.tb00834.x

Taylor, R. L. (1993). Instruments for the screeing, evaluation, and assessment of infants and toddlers. In D. M. Bryant \& M. A. Graham (Eds.), Implementing early intervention: From research to effective practice. New York: The Guilford Press.

Tella, A. (2007). The impact of motivation on student's academic achievement and learning outcomes in mathematics among secondary school students in Nigeria. Eurasia Journal of Mathematics, Science \& Technology Education, 3(2), 149-156. https://doi.org/10.12973/ejmste/75390

Trautwein, U., Marsh, H. W., Nagengast, B., Lüdtke, O., Nagy, G., \& Jonkmann, K. (2012). Probing for the multiplicative term in modern expectancy-value theory: A latent interaction modeling study. Journal of 
Educational Psychology, 104(3), 763. https://doi.org/10.1037/a0027470

Usher, E. L., \& Pajares, F. (2006). Sources of academic and self-regulatory efficacy beliefs of entering middle school students. Contemporary Educational Psychology, 31(2), 125-141. https://doi.org/10.1016/j.cedpsych.2005.03.002

Usher, E. L., \& Pajares, F. (2009). Sources of self-efficacy in mathematics: A validation study. Contemporary Educational Psychology, 34(1), 89-101. https://doi.org/10.1016/j.cedpsych.2008.09.002

VanTassel-Baska, J. (1990). A practical guide to counseling the gifted in a school setting: The council for Exceptional Children (2nd ed.). Reston, Virginia: ERIC Clearinghouse on Handicapped and Gifted Children.

Wagner, H., \& Zimmermann, B. (1986). Identification and fostering of mathematically gifted students. Educational Studies in Mathematics, 17(3), 243-260. https://doi.org/10.1007/BF00305072

Wang, Y. (2008). On cognitive foundations of creativity and the cognitive process of creation. In Cognitive Informatics, 2008. ICCI 2008. 7th IEEE International Conference on (pp. 104-113). IEEE.

Webb, J. T. (1982). Guiding the gifted child: A practical source for parents and teachers. Columbus: Ohio Psychology Publishing.

Webb, J. T., Meckstroth, E. A., \& Tolan, S. S. (1982). Guiding the gifted child: A practical source for parents and teachers. Scottsdale, AZ: Gifted Psychology Press (formerly Ohio Psychology Press).

Wigfield, A., \& Cambria, J. (2010). Expectancy-value theory: Retrospective and prospective. In T. C. Urdan \& S. A. Karabenick (Eds.), The decade ahead: Theoretical perspectives on motivation and achievement (pp. 35-70). Emerald Group Publishing Limited. https://doi.org/10.1108/S0749-7423(2010)000016A005

Wigfield, A., \& Eccles, J. S. (1992). The development of achievement task values: A theoretical analysis. Developmental Review, 12(3), 265-310. https://doi.org/10.1016/0273-2297(92)90011-P

Wigfield, A., \& Eccles, J. S. (2000). Expectancy-value theory of achievement motivation. Contemporary Educational Psychology, 25(1), 68-81. https://doi.org/10.1006/ceps.1999.1015

Wigfield, A., Eccles, J. S., Yoon, K. S., Harold, R. D., Arbreton, A. J., Freedman-Doan, C., \& Blumenfeld, P. C. (1997). Change in children's competence beliefs and subjective task values across the elementary school years: A 3-year study. Journal of Educational Psychology, 89(3), 451. https://doi.org/10.1037/0022-0663.89.3.451

Wigfield, A., Tonks, S., \& Klauda, S. L. (2009). Expectancy-value theory. In K. R. Wentzel \& A. Wigfield (Eds.), Handbook of motivation at school (pp. 55-75). New York: Routledge.

Xiang, P., McBride, R. E., \& Bruene, A. (2006). Fourth-grade students' motivational changes in an elementary physical education running program. Research Quarterly for Exercise and Sport,77(2), 195-207. https://doi.org/10.1080/02701367.2006.10599354

Yurt, E. (2014). The predictive power of self-efficacy sources for mathematics achievement. Egitim ve Bilim, 39(176). https://doi.org/10.15390/EB.2014.3443

Yurt, E., \& Akyol, Ş. (2015). Matematikte benlik ve görev algısı envanterinin Türkçeye uyarlanması. Paper presented at the 24. National Education Science Conference, Niğde, Turkey.

Yurt, E., Kurnaz, A., \& Sahin, I. (2014). Analysis of education faculty students' attitudes towards e-learning according to different variables. Social Studies, 28(25), 53.

Zimmerman, D. L., \& Cressie, N. (1992). Mean squared prediction error in the spatial linear model with estimated covariance parameters. Annals of the Institute of Statistical Mathematics, 44(1), 27-43. https://doi.org/10.1007/BF00048668

\section{Copyrights}

Copyright for this article is retained by the author(s), with first publication rights granted to the journal.

This is an open-access article distributed under the terms and conditions of the Creative Commons Attribution license which permits unrestricted use, distribution, and reproduction in any medium, provided the original work is properly cited. 